\title{
Two years retrospective study of maxillofacial trauma at a tertiary center in North West Ethiopia
}

\author{
Amare Teshome $^{1 *} \mathbb{C}$, Getaneh Andualem ${ }^{1}$, Rediet Tsegie ${ }^{1}$ and Samuel Seifu ${ }^{2}$
}

\begin{abstract}
Background: Maxillofacial injury poses a challenge to oral and maxillofacial surgeons working in developing countries with limited resource and human power. The present study aimed to determine the etiology, pattern, and management of maxillofacial trauma in Gondar university of Gondar hospital.

Methods: A retrospective descriptive study design was used. Medical registration retrieving of patients with maxillofacial trauma visited dental center of University of Gondar Hospital from September 2013 to August 2015 was done. During data collection, etiology of trauma, pattern of fracture, treatment modality and complications were recorded using predesigned data collection template and analyzed using SPSS computer software version 20. Statistical analysis was done to show the sex distribution of maxillofacial trauma and the effect of alcohol intake on the incidence of trauma.

Results: During 2-year period, September 2013-August 2015, 326 patients of maxillofacial trauma were treated in the dental center of university of Gondar hospital. The mean age was 29.12 ( \pm 8.62$)$ with age range of 11-75 years. Majority of the study participants (47.2\%) were within the age group of 21-30 years. Eighty percent of the participants were male with a male to female ratio of 4.02:1. Interpersonal violence (75.8\%) and Road traffic accident (21.5\%) were the leading causes. Males are at high risk of maxillofacial trauma relative to females $(P<0.0001)$. There was high incidence of trauma in the weekend, rural residents, December to February, mandibular fractures and soft tissue injuries were the most common injuries. There was an associated injury in 79 (24.2\%) patients in head and neck area, thoracic, abdominal and extremities. Half of the patients were managed conservatively (49.7\%) with debridement and suture, while $45.7 \%$ of the patients were closed reduction and $4.6 \%$ were surgical open reduction. There were 25 post procedure complications especially in mandibular fractures.
\end{abstract}

Conclusion: Interpersonal violence was the major cause of maxillofacial trauma, while mandible and soft tissue were the most affected maxillofacial areas. The federal ministry of health, Ethiopia should have well-organized maxillofacial center in tertiary hospitals for emergency management to avoid morbidity and mortality.

Keywords: Maxillofacial trauma, Etiology, Treatment outcome, Interpersonal violence, Maxillofacial fracture

\section{Background}

An injury is defined as "a physical injury that occurred when human body sustained sudden force in amount that is beyond the verge of physical tolerance "or the result of a lack of one or more vital elements, such as oxygen" [1].

\footnotetext{
*Correspondence: teshomeamare78@yahoo.com

1 Department of Dentistry, College of Medicine and Health Sciences, University of Gondar, Gondar, Ethiopia

Full list of author information is available at the end of the article
}

The presence of trauma in the maxillofacial (MF) area have a substantial impact in the psychology and aesthetic of the patient and lays an everlasting effect on the behavior of the patient [2]. The presence of morbidity and mortality due to maxillofacial trauma is high even if there was a good recovery [3].

There is a varied etiology of maxillofacial trauma that differs from country to country due to cultural, socioeconomic and environmental factors $[4,5]$. Road traffic 
accidents, violence, fall and sport activities were the leading causes of maxillofacial trauma [6-11]. Interpersonal violence is the leading cause of maxillofacial trauma in developed countries, while road traffic accident is the leading in developing countries [7].

The incidence of maxillofacial trauma was high in males with male to female ratio of 5:1 in Zimbabwe [8] and in the age of 19-28 [10]. A study done in Braille showed that there was $90.9 \%$ of maxillofacial fracture in patients sustained maxillofacial trauma and maxillary bone fracture was the most commonly occurred fracture [10]. however, other study in Iran showed high incidence of mandibular fracture with a common site of body of the mandible [11].

Maxillofacial trauma involves soft tissues of the face and bones of the mandible, mid-facial and frontal bones [12]. the severity and pattern of the MF trauma depends on the anatomic site of trauma, magnitude of the force and direction of the force $[4,12]$.

The maxillofacial treatment depends on the pattern and severity of the trauma and may be conservatively with debridement and suture, closed reduction with arch bar or eyelets, or surgically with open reduction. Procedures with open reduction resulted satisfactory facial aesthetic, shortened duration of work absence, and preserves function early and reduced the incidence of complications [13].

Comprehensive data on the etiology and pattern of maxillofacial injuries is not readily available in Ethiopia. The aim of this study was to determine the etiology, pattern of trauma and management modalities on traumatic patients visited university of Gondar dental center.

\section{Methods}

We conducted a retrospective study in patients with maxillofacial trauma who treated in the dental center of university of Gondar hospital from September 2013 to August 2015. The hospital was founded in 1930s and serves as a tertiary hospital for the last 80 years. It is considered as a center of excellence teaching center in the northwest of Ethiopia. Patients with full-recorded medical record and above 10 years were included in the study. During the 2 years, three hundred seventy eight patients with maxillofacial trauma were treated in the dental center. However, fifty-two cases had incomplete record and excluded from the study. Data were collected from clinical notes from September 2015 to January 2016 using predesigned templates by three dental surgeons under the supervision of the principal investigator.

The data collected from the patient's record were; age, gender, cause of trauma, anatomic site of fracture, associated injuries, and type of treatment modality. The etiology of trauma was divided into four main categories: (i) violence, which include interpersonal violence and weapons; (ii) road traffic accidents involving automobiles, motorcycles and pedestrians; (iii) sport injuries; and (iv) fall; fall from ground or high level.

Maxillofacial fractures were diagnosed with clinical and imaging examination (conventional radiograph or CT scan). Maxillofacial injuries were classified according to location of trauma, types of injury, and etiology.

This research is in accordance with all ethical standards, and the ethical review committee of university of Gondar approved the project. Permission to review the medical records of the patients was also provided by the director of Gondar university hospital.

The collected data were coded and entered into Epi info version 7. Then it exported to IBM SPSS 20 (IBM Corp, Armonk, NY, USA) for analysis. Descriptive statistics were used to summarize the sociodemographic characteristics, cause of trauma, pattern of trauma/fracture and the type of complications.

\section{Results \\ Participant characteristics}

Three hundred twenty six patients with maxillofacial trauma were seen at dental clinic of university of Gondar between September 2013 and August 2015. Overall, 261() patients were male with a male to female ratio of 4.02:1. The mean age of the participants was $29.12( \pm 8.62)$ years (range 11-75 years) and the most commonly affected age group was $21-30$ years (47.24\%). The incidence of trauma was high in rural residents (Table 1).

\section{Cause of maxillofacial trauma}

The major cause of maxillofacial trauma were; interpersonal violence (IPV) $(75.8 \% ; \mathrm{n}=247)$, road trafficking accident (RTA) $(21.5 \%, \mathrm{n}=70)$ and others $(2.7 \%, \mathrm{n}=9)$. Interpersonal violence was the leading cause of maxillofacial trauma in patients who take alcohol. Moreover, young patients (11-30 years) were mainly affected by IPV whereas middle and old age ( $>40$ years) were of RTA (Table 1). Almost all (87.6\%) cases of maxillofacial trauma incidents in the rural residents was due to IPV (Table 1).

\section{Alcohol intake and maxillofacial trauma}

Overall, alcohol intake was recorded in $35.6 \%$ of the patients, mainly in males $(92.2 \%)(\mathrm{P}<0.0001)$. Males and 21-30 years old patients were taken alcohol such as; beer, wine, whisk, traditional drinks (Tela, Areki, Teji) etc. before the incidence of the trauma (Table 2).

\section{Time lag between trauma incidence and dental visit}

The majority of patients (46.6\%) arrived to dental clinic within $24 \mathrm{~h}$. Daytime injuries occurred in majority of the cases $(71.62 \%)$ (Fig. 1). Most of the cases were occurred 
Table 1 Frequency of the etiology of maxillofacial injuries in relation to age group and sex $(n=326)$ among patients seen in dental center of university of Gondar hospital, 2013-2015

\begin{tabular}{llll} 
Etiology & & & $\begin{array}{l}\text { P value/Chi } \\
\text { square }\end{array}$ \\
\cline { 1 - 2 } $\begin{array}{lll}\text { Interpersonal } \\
\text { violence }\end{array}$ & $\begin{array}{l}\text { Road } \\
\text { traffic } \\
\text { accident }\end{array}$ & $\begin{array}{l}\text { Others } \\
\text { (fall, sport } \\
\text { etc.) }\end{array}$ & \\
& & &
\end{tabular}

\begin{tabular}{lrrrl}
\hline $\begin{array}{l}\text { Gender } \\
\text { Male }\end{array}$ & 211 & 44 & 6 & $P<0.0001$ \\
Female & 36 & 26 & 3 & $X^{2}=18.44$ \\
Age & & 16 & 3 & $P<0.00001$ \\
$11-20$ & 50 & 32 & 5 & $X^{2}=66.0355$ \\
$21-30$ & 117 & 13 & 1 & \\
$31-40$ & 40 & 39 & 1 & \\
$>40$ & 9 & & & \\
Residency & & 48 & 4 & $X^{2}=51.2267$ \\
Urban & 57 & 22 & 5 & \\
Rural & 190 & & & \\
\hline
\end{tabular}

Table 2 The association between alcohol intake and maxillofacial trauma incidence among patients visited dental center of university of Gondar Hospital, 2013-2015

\begin{tabular}{lcrl}
\hline $\begin{array}{l}\text { Sociodemographic } \\
\text { characteristics }\end{array}$ & \multicolumn{2}{l}{\begin{tabular}{l} 
Maxillofacial trauma \\
\cline { 2 - 3 }
\end{tabular}} & $\begin{array}{l}\text { P value/Chi } \\
\text { square }\end{array}$ \\
\hline Gender & $107(92.2 \%)$ & $1549(73.3 \%)$ & $P<0.0001$ \\
Male & $9(7.8 \%)$ & $56(26.7 \%)$ & $X^{2}=16.7353$ \\
Female & & & \\
Age & $27(23.3 \%)$ & $42(20 \%)$ & $P<0.001$ \\
$11-20$ & $67(57.6 \%)$ & $87(41.5 \%)$ & $X^{2}=18.7621$ \\
$21-30$ & $17(14.7 \%)$ & $37(17.6 \%)$ & \\
$31-40$ & $5(4.4 \%)$ & $44(20.9 \%)$ & \\
$>40$ & & & \\
\hline
\end{tabular}

in the weekend (39\%), and from December to March with a peak level on February (Fig. 2).

\section{Pattern of maxillofacial trauma}

Of the 326 maxillofacial injuries, 162 (49.4\%) were only soft tissue injuries; laceration, contusion, and abrasion. Maxillofacial fracture occurred in 164 (50.61\%) patients, of these, $123(75 \%)$ of patients had mandibular fracture (Table 3).

\section{Associated injuries}

The concomitant injuries were observed in 79 (24.23\%) of patients with maxillofacial injury. Of these, extremities (43.04\%; 52.3\% were in the upper extremities) and head and neck (31.65\%) were commonly affected (Table 4).

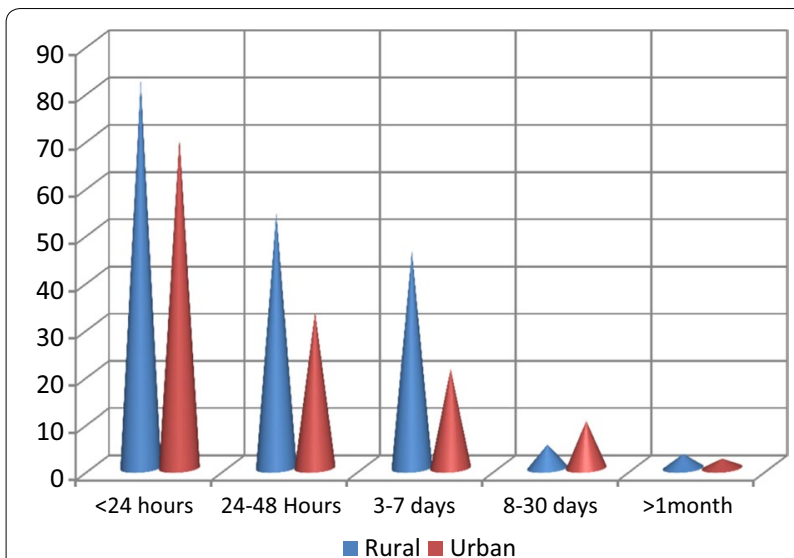

Fig. 1 Frequency of time lag between trauma incidences to dental visit according to residency $(n=326)$ among patients visited dental clinic of Gondar university, 2013-2015

\section{Treatment modalities}

Two hundred sixty-three $(80.67 \%)$ patients were required surgical treatment, of which debridement (76.53\%) was the most common surgical procedure performed. Out of 164 patients with maxillofacial fractures, 149 (90.85\%) patients treated by closed reduction using mandibulomaxillary fixation, either with eyelet wiring methods or arch bars while 15 (9.15\%) patients were managed by open reduction and intraosseous wiring. The patients were reviewed for 6 months (every 2 week for the first 6 weeks and every month from 6 week to 6 months).

\section{Post treatment complications}

In the 2 years maxillofacial trauma cases, complications occurred in 25 patients (7.7\%). Most of the complications were in the mandible: at the angle (7 cases), symphysis (3 cases), body (6 cases), and body and angle (3 cases) while six cases were occurred in the maxilla. The complications were; malocclusion, surgical site infection, chronic sinusitis and non-union. Malocclusion (48\%) and trauma site infections $(28 \%)$ were the most common complications recorded (Table 5).

\section{Discussion}

Trauma, the leading cause of death in the first 40 years of lie, could be considered as the cause of productivity loss due to loss of working hours than cancer and heart diseases combined. Maxillofacial traumas are a common part of the multiple traumas resulting from road traffic accident, assault, sport, and fall. This cause differs from country to country due to cultural, environmental and socioeconomic factors $[6,14]$.

The incidence of maxillofacial trauma was fairly constant with seasonal variation as showed in the literature 


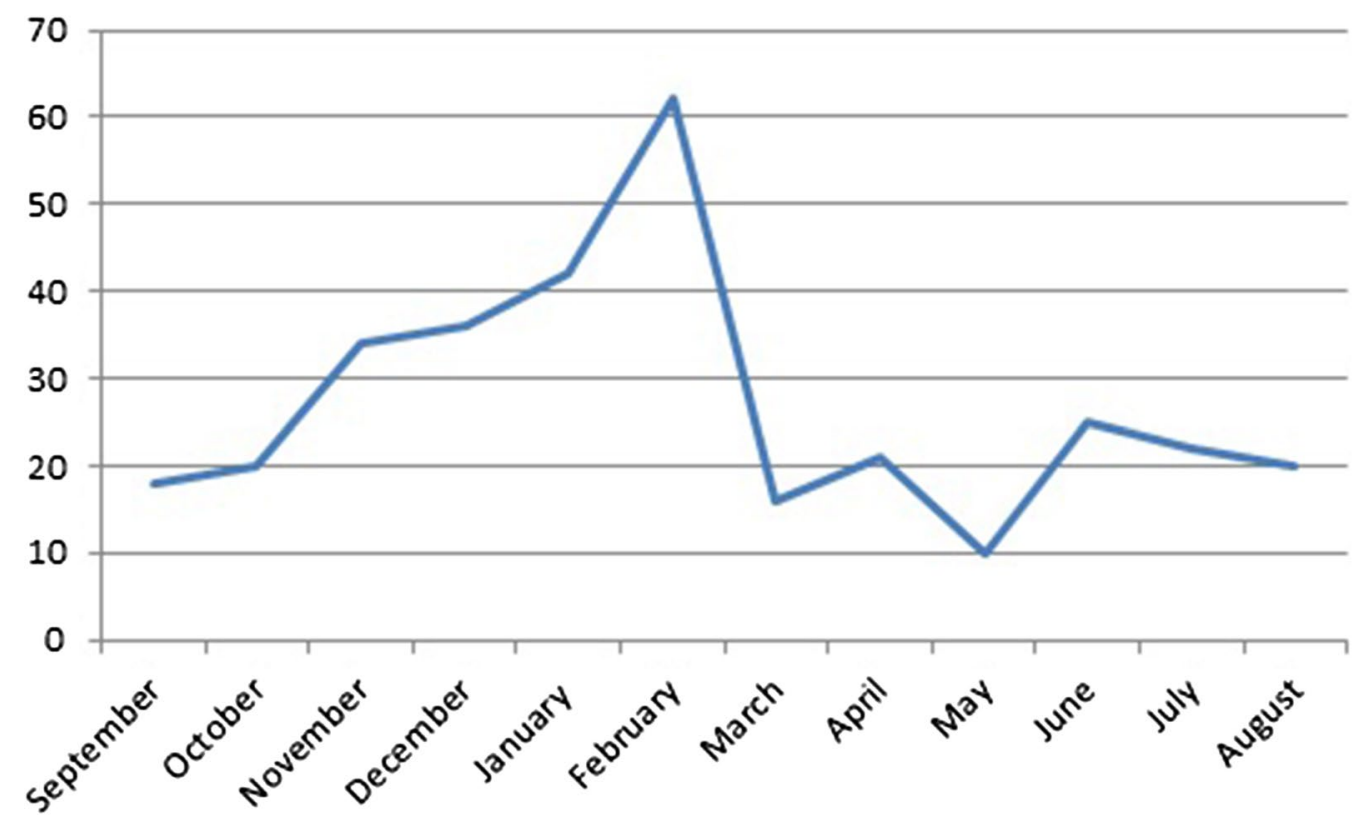

Fig. 2 Monthly distribution of maxillofacial trauma incidence among patients visited dental center of university of Gondar hospital, 2013-2015

Table 3 Pattern of maxillofacial fracture among patients visited dental clinic of university of Gondar hospital ( $\mathrm{n}=164)$, 2013-2015

\begin{tabular}{lcl}
\hline Type of fracture & Frequency & Percent (\%) \\
\hline Mandibular fractures & 123 & 75 \\
Condyle & 16 & 9.8 \\
Ramus & 10 & 6.1 \\
Angle & 19 & 11.6 \\
Body & 54 & 32.9 \\
Symphysis/parasymphysis & 24 & 14.6 \\
Nasal fractures & 3 & 1.8 \\
Frontal fractures & 1 & 0.6 \\
Zygomatic fractures & 4 & 2.4 \\
Maxillary fractures & 33 & 20.2 \\
Le fort I & 27 & 16.5 \\
Le fort II & 5 & 3.1 \\
Le fort III & 1 & 0.6 \\
\hline
\end{tabular}

$[15,16]$. However, in the present study the incidence was high from October to March with a peak level on February which coincides with a study done in Iran [11] and western Nepal [17]. This might be due to the existence of many public holidays in the country during this months and majority of the community spend their time work free and takes alcohol as recreation. Moreover, there was high incidence of trauma in the weekend (Saturday and Sunday).
Table 4 Associated injuries among patients visited dental clinic of university of Gondar hospital $(n=79), 2013-2015$

\begin{tabular}{lcl}
\hline Associated injuries & Frequency & Percentage (\%) \\
\hline Head and neck injury & 25 & 31.7 \\
Thoracic injury & 8 & 10.1 \\
Abdominal injuries & 12 & 15.2 \\
Extremities injuries & & \\
Upper extremities & 23 & 29.1 \\
Lower extremities & 11 & 13.9 \\
Total & 79 & 100 \\
\hline
\end{tabular}

The morbidity and mortality of traumatic patients is depend on their arrival time to the health institution. Majority (46.6\%) of the patients visited university of Gondar dental clinic with in $24 \mathrm{~h}$ of trauma exposure. It agrees with a study conducted in Nigeria [18] and France [19].

The sex distribution of maxillofacial trauma incidence is highly frequent in males and is coincides with studies conducted elsewhere $[17,19-24]$. The overall male to female ratio was 4.02:1 which corresponds with the study done in India (4.2:1) [25], and Zimbabwe (5:1) [8]. This might be due to that men tend to be more often involved in aggressive and conflict-ridden situations and are mostly involved in outdoor activities than women.

This study showed high incidence of trauma in young adults in their third decades (21-30 years) which is in 
Table 5 Type of post treatment complications among maxillofacial trauma patients visited university of Gondar hospital $(n=25), 2013-2015$

\begin{tabular}{lcc}
\hline Complications & Frequency & Percent (\%) \\
\hline Malocclusion & 12 & 48 \\
Surgical site infection & 7 & 28 \\
Chronic sinusitis & 2 & 8 \\
Non-union & 4 & 16 \\
\hline
\end{tabular}

agreement with many other studies [9, 11, 20, 23-27]. This may reflect this age group is more energetic and aggressive than others. More over, rural residents were more affected by maxillofacial trauma than urban residents. This is due to the existence of revenge, rural residents spent there time free from work from December to March and engaged in alcoholic drinks.

The present study revealed that interpersonal violence (75.8\%) was the leading cause of maxillofacial trauma. In this respect it agrees with studies conducted in Kenya [27], Brazil [4], France [19], Bulgaria [28], and Johannesburg [29]. However, some other literature [7, 9, 11, 18, 22, $23,30,31]$ showed RTA as a major cause of maxillofacial trauma. This result may reflect the fact that majority of the participants were rural residents and adults.

This study revealed $1 / 3$ rd of the patients had alcoholic ingestion before the incidence of maxillofacial trauma. This result supported the hypothesis that alcohol intake and maxillofacial injury in adults has a strong relationship $[14,32]$. There was a significant association between alcohol intake and maxillofacial trauma in males $(\mathrm{P}<0.0001)$ and adults $(21-30$ years $)(P=0.0003)$. This is because of the impact of alcohol on balance, and brings aggression.

When maxillofacial area is injured, mandible is the most vulnerable bone than the mid facial bones $[11,18,19,24$, $25,30]$. The present study revealed that $75 \%$ of maxillofacial bone fractures was occurred in the mandible. This fractures was common in body (32.9\%), symphysis/parasymphysis (14.6\%) and angle (11.6\%) of the mandible. This could be due to the mandible is mobile and has less bony support.

This study revealed high incidence of concomitant injuries to the head and neck (31.7\%) and, upper limb (29.1\%). This finding is inline with previous studies that showed high incidence of injury to the limb $[33,34]$. This is due to the victims use their arm to defend themselves from assaults.

Previous studies done in Iran [11] and South Africa [29] showed that majority of maxillofacial fractures were treated with open reduction and has low post operation complications. The present study is not inline with this findings where only $9.15 \%$ of the patients had open reduction. This variation is because of the absence of qualified experts in maxillofacial surgery in the study area. However, a study done in Nigeria has similar finding with our studies [18]. Surgical management of maxillofacial fracture with open reduction promises a shortened period of bone fixation, rapid restoration of anatomy and function, bony union with less callus formation [35].

There was $15.2 \%$ of complications observed after 6 months followup period which is lower than the result found by Chalya et al. [36]. The presence of this much incidence of complication may be due to most procedures are done by closed reduction due to the absence of maxillofacial surgeons.

In Ethiopia, the service of maxillofacial and dentistry in general is neglected due to the absence of qualified maxillofacial surgeons, governments priority to infectious diseased and the absence of dental and maxillofacial equipment in the country. The absence of experts in oral and maxillofacial and plastic surgery for internal fixation and open reduction are a major obstacles in achieving early healing and restoration of cosmetics in facial trauma patients.

Limitation of this study was; some of patient medical records were incomplete and were excluded from the study. Therefore a larger sample size prospective study should be done to make a conclusive finding on the epidemiology of maxillofacial trauma in Ethiopia.

\section{Conclusion}

Interpersonal violence and road trafficking accidents were the leading causes of maxillofacial trauma. Males and 21-30 years aged were the most affected groups, while mandibular fracture and soft tissue injuries were the commonly occurring type of injuries. Majority of maxillofacial fractures were managed by closed reduction.

\section{Abbreviations}

IPV: interpersonal violence; RTA: road traffic accident; MF: maxillofacial.

\section{Authors' contributions}

AT: study design, data collection, data analysis, manuscript writing and editing and submission; GA: data collection, data analysis, manuscript writing and submission; RT: data analysis, manuscript writing and editing, manuscript submission, SS: study design, data collection, data analysis and manuscript writing. All authors read and approved the final manuscript.

\section{Author details}

${ }^{1}$ Department of Dentistry, College of Medicine and Health Sciences, University of Gondar, Gondar, Ethiopia. ${ }^{2}$ Department of Stomatology, College of Medicine and Health Sciences, Mekelle University, Mekelle, Ethiopia.

\section{Acknowledgements}

The authors are grateful to university of Gondar ethical review committee for the ethical clearance and to all those who were involved in the care of our patients. Lastly, the authors wish to thank all the staffs of the medical record office of Gondar university hospital.

\section{Competing interests}

The authors declare that they have no competing interests.

Availability of data and materials

No data and images of the participants will be disclosed due to the agreement between the participants and the institutional ethical review board. 


\section{Consent to publish \\ Not applicable.}

\section{Ethics approval and consent to participate}

The institutional review board of University of Gondar approved the study with Reference Number of O/N/P/RCS/05/622/2016. A verbal consent was taken for each patient and also assent was taken for under 16 years children form their parents or legal Guardians.

\section{Funding}

The authors declared that there was no funding.

\section{Publisher's Note}

Springer Nature remains neutral with regard to jurisdictional claims in published maps and institutional affiliations.

Received: 20 May 2016 Accepted: 22 July 2017

Published online: 08 August 2017

\section{References}

1. Holder Y, Peden M, Krug E, et al., editors. Injury surveillance guidelines. Geneva: World Health Organization; 2001.

2. De Sousa A. Psychological issues in acquired facial trauma. Indian J Plast Surg. 2010:43(2):200.

3. Wymann NME, Hölzle A, Zachariou Z, lizuka T. Pediatric craniofacial trauma. J Oral Maxillofac Surg. 2008;66(1):58-64.

4. Leles JLR, dos Santos ÊJ, Jorge FD, da Silva ET, Leles CR. Risk factors for maxillofacial injuries in a Brazilian emergency hospital sample. J Appl Oral Sci. 2010;18(1):23-9.

5. Allareddy $V$, Allareddy $V$, Nalliah RP. Epidemiology of facial fracture injuries. J Oral Maxillofac Surg. 2011;69(10):2613-8.

6. Fonsceca RJ. Mandibular fractures. Oral and maxillofacial trauma. USA Elsevier Sanders; 2005

7. Adebayo ET, Ajike OS, Adekeye EO. Analysis of the pattern of maxillofacial fractures in Kaduna, Nigeria. Br J Oral Maxillofac Surg. 2003:41(6):396-400.

8. Khan AA. A retrospective study of injuries to the maxillofacial skeleton in Harare, Zimbabwe. Br J Oral Maxillofac Surg. 1988;26(5):435-9.

9. Cavalcanti AL, Bezerra PM, de Oliveira DM, Granville-Garcia AF. Maxillofacial injuries and dental trauma in patients aged 19-80 years, Recife, Brazil. Rev Esp Cir Oral Maxilofac. 2010;32(1):11-6.

10. Murphy RX Jr, Birmingham KL, Okunski WJ, Wasser T. The influence of airbag and restraining devices on the patterns of facial trauma in motor vehicle collisions. Plast Reconstr Surg. 2000;105(2):516-20.

11. Arabion HR, Tabrizi R, Aliabadi E, Gholami M, Zarei K. A retrospective analysis of maxillofacial trauma in Shiraz, Iran: a 6-year-study of 768 patients (2004-2010). J Dent. 2014;15(1):15.

12. Khitab U, Ansari SR, Khan A, Khan MT, Abdus-Salam. Occurrence and characteristics of maxillofacial injuries-a study. Pak Oral Dent J. 2010;30(1):57-61.

13. Pyungtanasup K. The epidemiology of mandibular fractures treated at Chiang Mai university hospital: a review of 198 cases. J Med Assoc Thai. 2008;91(6):868-74.

14. Telfer MR, Jones GM, Shepherd JP. Trends in the aetiology of maxillofacial fractures in the United Kingdom (1977-1987). Br J Oral Maxillofac Surg. 1991;29(4):250-5.

15. Haug RH, Foss J. Maxillofacial injuries in the pediatric patient. Oral Surg Oral Med Oral Pathol Oral Radiol Endodontol. 2000;90(2):126-34.

16. Jaber MA, Porter SR. Maxillofacial injuries in 209 Libyan children under 13 years of age. Int J Paediatr Dent. 1997;7(1):39-40.

17. Khadka R, Chaurasia NK. Four years prospective study of the maxillofacial trauma at a tertiary center in western Nepal. J Orofac Sci. 2014;6(2):78.

18. Ogundipe OK, Afolabi AO, Adebayo O. Maxillofacial fractures in Owo, south western Nigeria. A 4 year retrospective review of pattern and treatment outcome. Dentistry. 2012;2:132-4.

19. Pham-Dang N, Barthélémy I, Orliaguet T, Artola A, Mondié J-M, Dallel R. Etiology, distribution, treatment modalities and complications of maxillofacial fractures. Med Oral Patol Oral Cir Bucal Ed Inglesa. 2014;19(3):261-9
20. Abdullah WA, Al-Mutairi K, Al-Ali Y, Al-Soghier A, Al-Shnwani A. Patterns and etiology of maxillofacial fractures in Riyadh City, Saudi Arabia. Saudi Dent J. 2013;25(1):33-8.

21. Wood EB, Freer TJ. Incidence and aetiology of facial injuries resulting from motor vehicle accidents in queensland for a three-year period. Aust Dent J. 2001;46(4):284-8.

22. Andreas ZJ, Benoit S, Olivier L, Nikola S, Hanna T, Tateyuki I. Incidence, aetiology and pattern of mandibular fractures in central Switzerland. Swiss Med Wkly. 2011;141:132-7.

23. Garg $\vee$, Singh $H$, Vij K. Trends of maxillofacial trauma at tertiary care hospital in rural area of southern Punjab. J Indian Acad Forensic Med. 2012;34(1):971-3.

24. Guruprasad Y, Hemavathy OR, Giraddi G, Shetty JN. An assessment of etiological spectrum and injury characteristics among maxillofacial trauma patients of government dental college and research institute, Bangalore. J Nat Sci Biol Med. 2014;5(1):47.

25. Bali RK, Sharma P, Garg A, Dhillon G. A comprehensive study on maxillofacial trauma conducted in Yamunanagar, India. J Inj Violence Res. 2013;5(2):108-16

26. Ayana B, Ahmed E. Interpersonal violence related injury at St Luke hospital, Oromia Region, Ethiopia. East Cent Afr J Surg. 2012;17(1):37-42.

27. Owino RO, Macigo FG, Onyango FJ. Pattern and aetiology of mandibular fractures at Kenyatta national hospital. Afr J Oral Health Sci. 2003;4(1):178-80.

28. Rubiev M. A retrospective analysis of facial fracture etiologies. J IMAB Annu Proc Sci Pap. 2012;18(2):153-4.

29. Desai J, Lownie JF, Cleaton-Jones P. Prospective audit of mandibular fractures at the Charlotte Maxeke Johannesburg academic hospital. S Afr J Surg. 2010:48(4):122-6.

30. Batista AM, de Ferreira F, Marques LS, Ramos-Jorge ML, Ferreira MC. Risk factors associated with facial fractures. Braz Oral Res. 2012;26(2):119-25.

31. Nordberg E. Injuries as a public health problem in sub-Saharan Africa: epidemiology and prospects for control. East Afr Med J. 2000;77(12 Suppl):S1-43

32. Deliverska E. The role of alcohol involvement in maxillofacial trauma. J IMAB Annu Proc Sci Pap. 2012;18(2):147-9.

33. Saddki N, Suhaimi AA, Daud R. Maxillofacial injuries associated with intimate partner violence in women. BMC Public Health. 2010;10(1):268.

34. Le BT, Dierks EJ, Ueeck BA, Homer LD, Potter BF. Maxillofacial injuries associated with domestic violence. J Oral Maxillofac Surg. 2001;59(11):1277-83

35. Abbas I, Ali K. Management of mandibular fractures a prospective study. Pak Oral Dent. 2002;22:151-2.

36. Chalya PL, Mchembe M, Mabula JB, Kanumba ES, Gilyoma JM. Etiological spectrum, injury characteristics and treatment outcome of maxillofacial injuries in a Tanzanian teaching hospital. J Trauma Manag Outcomes. 2011:5(1):1-6.

\section{Submit your next manuscript to BioMed Central} and we will help you at every step:

- We accept pre-submission inquiries

- Our selector tool helps you to find the most relevant journal

- We provide round the clock customer support

- Convenient online submission

- Thorough peer review

- Inclusion in PubMed and all major indexing services

- Maximum visibility for your research

Submit your manuscript at www.biomedcentral com/submit
C BioMed Central 